2 The "very competent critic" has not been identified.

3 Southern Field and Fireside, 2, No. 3 (9 June 1860), 20.

4 Rayburn S. Moore, "The Literary World Gone Mad: Hayne on Whitman," The Southern Literary fournal, 10, No. 1 (Fall 1977), 76.

5 Southern Field and Fireside, 1, No. 43 (17 March 1860), 338.

\title{
WHITMAN ON WAR: FOUR POEMS FROM DRUM-TAPS
}

The order in which the poems of Leaves of Grass appear is often of dubious significance, despite Whitman's occasional claims to the contrary; but at times it is crucial. Perhaps most notably in the Drum-Taps section of the book, sequence frequently enriches and enhances meaning: particular poems are best seen not in isolation, but as part of an ordered and purposeful development.

Such a sequence is the series of four poems beginning with "Cavalry Crossing a Ford" and including "Bivouac on a Mountain Side," "An Army Corps on the March," and "By the Bivouac's Fitful Flame." All are of approximately equal length, ranging from seven to ten lines, and their arrangement is neatly symmetrical. As the titles indicate, there are two poems involving motion ("Crossing," "On the March"), each followed by a "bivouac" poem of stopping; the motion poems take place during the day, the bivouac poems during the night. The sunlight of one group is balanced by the firelight of the other. Comparing each poem with its counterpart reveals a progression of significant intent.

In "Cavalry Crossing a Ford" colors are a prominent feature: the green islands, the silvery river, the brown-faced men, the scarlet and blue and white of the flags. It is a lovely tableau, serene and undisturbed. The pace is leisurely: the horses, we are told, "loitering stop to drink," and among the men, "the negligent rest on their saddles" (my emphasis). It is a time when one can loiter and be negligent, when it is possible to enjoy the sunshine and the "musical clank" of movement. Everything in the poem suggests that these are new troops untried in battle; their weapons are so shiny that they "flash in the sun," and the white flags are still "snowy white," fluttering "gayly" in the wind. It is a time for gaiety; unpressed and unhurried, the troops pass through a lovely landscape, unmindful of what is to come.

In the second "motion" poem, "An Army Corps on the March," all has changed. Like the first, it contains sounds, but instead of the pleasing "musical clank" of "Cavalry Crossing a Ford," the sounds are threatening: we hear rifle shots and the ominous rumbling of wagon wheels. There is no loitering here, no opportunity for negligence; the troops are engaged in battle, and movement is forced and frantic ("the swarming ranks press on and on, the dense brigades press on"). The sun still shines, but there is no bright flashing and sparkle; the glittering, such as it is, is dim, and the men are dust-covered. We see no flags decorating the landscape, not even any individual men; only "swarming ranks" and "dense brigades." In "Cavalry Crossing a Ford" there was time to stop, so that each person could be seen as "a picture," but not here, where the frenzy of movement under attack enforces anonymity. Personal identity becomes, under the circumstances, irrelevant if not impossible. Instead of the delicate movements of "Cavalry Crossing a Ford," we 
now have rumbling wheels and sweating horses: it is power that matters, not grace. In comparison to the movement of "An Army Corps on the March," that of "Cavalry" seems a dance-a light-hearted quadrille, perhaps, in an elegant setting of bright adornments.

The two poems of stopping are similarly contrasted. Following "Cavalry Crossing a Ford" we have "Bivouac on a Mountain Side." In the first line the speaker remarks that he sees "a traveling army halting," and in line 6 he notes "the shadowy forms of men and horses," but apart from these references the speaker is hardly conscious of the men around him or of the military purpose of their mission. His thoughts are elsewhere: first, on the scenery, the "fertile valley," the barns and orchards, the terraced mountain broken with rocks and cedars, the campfires; and second, on the beautiful summer sky at night. In the last line the speaker loses himself in joyful wonder as his gaze turns upward: "And over all the sky-the sky! far, far out of reach, studded, breaking out, the eternal stars."

There is no reason in this poem to suspect that battle is a matter of much concern. The speaker is not anxious or worried about war; he luxuriates on the scene rather than contemplates the reason he is there. He might as well be on a camping trip. In the second "bivouac" poem, however, in "By the Bivouac's Fitful Flame," there is a profound change. The speaker's thoughts are anxious and sombre. He has been through battle, as described in "An Army Corps on the March," and he has seen men die; now, as he watches about the uneasy flame of a campfire, he sees nature not as wondrous and beautiful, but as hostile and threatening: "The shrubs and trees (as I lift my eyes they seem to be stealthily watching me)." Nature is no friend to men in battle; it is, rather, a constant source of danger. The speaker's thoughts are those of a man confronting the possibility of death, perhaps on the next day; understandably, his mind turns to the past, to home, and to those far away, whom he may never see again. The poem is solemn and filled with tension; it offers nothing of consolation.

These four poems clearly make up a distinct unit, symmetrical in their arrangement and focus. Together they take us not only through Whitman's changing attitudes toward war, but also through those of the nation in general, from the lighthearted naiveté that sees war as an elegant game, with flags and shiny weapons and troops riding jauntily on horseback, to the realism that knows war for the grim business it is, a matter for grief and regret rather than celebration.

With powerful effect, in "Come Up from the Fields Father," the first poem that follows this four-poem sequence, Whitman focuses on those whom the speaker of "By the Bivouac's Fitful Flame" might have been thinking of, those far away, at home. The poem takes us to Ohio, to a family whose son has been killed in the war. Ironically, just as they receive a letter saying that he has been wounded but will soon be better, he is already dead; and the poem concludes with a picture of the mother after she has learned the bitter truth:

She with thin form presently drest in black,

By day her meals untouch'd, then at night fitfully sleeping, often waking,

In the midnight waking, weeping, longing with one deep longing, 
O that she might withdraw unnoticed, silent from life escape and withdraw,

To follow, to seek, to be with her dear dead son. (11. 33-37)

This is what the gaiety of "Cavalry Crossing a Ford" has come to; this is what war finally means. It is characteristic of Whitman's profound compassion that he so often takes us not to the inexperienced anticipation of battle, with its shouts and exuberant flag-waving, nor to the battle itself, with its shows of heroism and bravado, but to the wreckage that follows the combat, in which we see the human cost, the dead, the dying, the mutilated, the ruined lives. This, he insists, is the truth of war: if we are to have it, let us see the thing as it is, without pretense and without illusion. If then we choose it, we will get what we want, perhaps what we deserve as well; but war is so wretched a thing that we must not let our choice be governed by deception.

It is curious that Whitman, so often condemned for his extreme romanticism, as in the familiar charge that he lacked a sense of evil, should in this matter turn out to be such an unflinching realist; but whatever the justice of the accusations made against him, when it came to war, he could not shine upon it the light that never was, the light of the creative imagination, but insisted on seeing it as it was, unadorned and unembellished. Even so, words failed; as he said in Specimen Days, "the real war will never get in the books." Still, he did what he could, perhaps as much as anyone could. If Drum-Taps does not give us the real war, it gives us as much as we need to know. 